his duties, General Clifford went on :- "I am perfectly certain from what I have seen that Dr. Taylor cannot take the temperature of a patient no more than he can fly. From my own personal observation it appears that Dr. Taylor is unable to recognise different gentlemen coming into this institution. I say that it is a saving to the ratepayers to have Dr. Taylor in a position to discharge his duties properly, but in my opinion he is physically incapable of discharging these duties. I would move that we have experi opinion as to his eyesight."

"When pigs begin to fly," as they say in Ireland, General Clifford will probably be a good judge of the duties of a medical superintendent, and have some valuable original opinions as to temperzture taking. We can quite believe that Dr. Taylor may experience some difficulty in recognising a gentleman among some of those who come into the institution, but surely this cannot be a disqualification for a post connected with the Monaghan and Cavan Asylum.

Mr. Mullen, we are told, moved a negative. He said-" Because Dr. Taylor is doing his duty fearlessly and conscientiously, as he has done up to the present, General Clifford comes forward and demands that someone else should take his place. I move now that we do not receive General Clifford's motion."

The Most Rev. Dr. Owens, Roman Catholic Bishop of Clogher, supported Mr. Mullen. In a very generous and handsome speech, he upheld the character and capacity of the unfortunate doctor against the enemies who were baiting him. Speaking with the intimate personal knowledge which his position gave him, as well as the fact that he lives close to the asylum, has a right of way through its grounds, and has been longer and more closely associated with it than any other member of the Committee, he testified to the excellence of Dr. Taylor's services, and said he thought it would be very hard to get a more capable official. He had one quarrel with Dr. Taylor, and as to that he said-"I reproached him for not taking the proper steps to put an end to the abusive charges that were being made against him and have damages obtained against the gentlemen who made the accusations." He went on to say that he regarded the present motion as libellous, and that if he were the medical superintendent he would take an action against its proposer for 610,000 or so. It would appear to us that the peculiar form which the resolution took was probably slyly arranged to dodge the law of libel, however. Casually the Bishop observed that the matter was before the Committee on a previous occasion and was defeated by a majority.

The scrimmage that followed on the just and kindly remarks of the Bishop would have little interest for our readers. It suffices to note three small items. First, it would appear that the Committee some time ago gave an order that the Medical Superintendent should take his turn with his assistants of visiting the wards at night. Can it be that the poor gentleman suffers from nyctalopia, and that this order was given in order to reveal his weakness? Secondly, it was suggested that the night attendant should be questioned as to Dr. Taylor's visits at nights. It is impossible to read an Irish story without observing how large a figure the spy and informer cuts in the narrative. We can quite imagine his being the leading spirit in an Irish asylum. Thirdly, a strong motive in some for voting against the motion was that an election of Committee is coming on, and that it would be wiser to leave the question of Dr. Taylor's vision to people who knew presumably nothing about it rather than to those who did. Why this notion ruled we are not sufficiently versed in local politics to tell, but the insinuation of sulne personal reason pro or con was very plain.

The motion of General Clifford was eventually negatived by six votes to five.

\title{
THE OPENING OF THE NEW CHAPEL AT JAMES MURRAY'S ROYAL ASYLUM AT PERTH.
}

The following extracts are from the pages of Excelsior:

"An important and impressive ceremony was witnessed at Murray's Royal Asylum on Thursday, September 29th, 1904, when the new chapel was solemnly dedicated, and the new villas adjoining were formally opened. The function was

I.I. 
attended by a large number of the subscribers to the Chapel Fund, including the Directors, Lord Provost and magistrates, clergymen, and friends of the Institution. The ministers, issuing from the robing room preceded by Dr. Urquhart, marched in processional order to the chapel, followed by the Lord Provost and magistrates in their civic robes and chains of office, while the Directors brought up the rear. Mr. F.S. Graves presided at the organ, with an efficient choir. The service was conducted by the Rev. J. W. Henderson, parish minster of Kinnoull and Chaplain of the Institution, the Rev. P. R. Landreth, of the West Parish Church, Perth, acting as moderator. The lessons were read by the Kev. D. W. Kennedy, of the Middle U.F. Church, Perth, and the Very Rev. the Dean of St. Andrews, while Dr. Robertson, Methven, preached a most eloquent and appropriate sermon.

"The service lasted about an hour, and at its conclusion the large company adjourned to the 'Browne Gallery' recreation hall, where a sumptuous repast was served. Lord Mansfield, Chairman of the Institution, presided.

"After luncheon the Chairman called upon Dr. Urquhart, who said he wished to say one word of grateful thanks to the subscribers for establishing and completing the chapel which had now been dedicated. Many were unable to be present, and he had a long list of letters of apology, with which he would not detain them. He would, however, quote from three letters, which were representative of all. Dr. Fraser, Commissioner in Lunacy, said: 'It is most gratifying that so many of your past and present patients have contributed to the cost of erecting the chapel. It is therefore largely a monument of gratitude.' Dr. Murray Lindsay, who acted as physician here during 1862, wrote: 'Nothing would have given me greater pleasure than to see the new chapel and the old place with its associations to me so dear and never to be forgotten. I heartily sympathise with your efforts, and congratulate you on the completion of the chapel, which could not have been accomplished without an enlightened and liberal Board of Directors.' Mr. James Ritchie, C.E., long a valued adviser, and a Director, wrote: "I am sure it must be a great and constant gratification to you, these wonderful improvements on so beneficial an Institution-the extent and value of which only such old stagers as Mr. John Dickson and myself can fully appreciate.' Dr. Urquhart concluded by intimating to the subscribers the gratifying fact that the chapel had been opened practically free of debt.

"After the loyal toasts had been honoured, Lord Mansfield called for the toast of the day.

"Sir James Crichton-Browne, in proposing 'James Murray's Royal Asylum,' contrasted the new chapel with the little rugged, ruined chapel of Strath Fillan there which was so long a shrine for the cure of the mentally deranged, to which those stricken with madness in this district in bygone times were carried after being dipped in-

$$
\text { Whose spring can frenzied dreams dispel, }
$$

And the crazed brain restore.'

"The proceedings closed with Lord Mansfield proposing the health of Dr. Urquhart, which was drunk amidst loud applause."

\section{CORRESPONDENCE.}

\section{Female Nursing of Insane Men.}

From Dr. Grorge M. Robertson, Stirling District Asylum, Larbert.

I request permission to record a few observations on the above subject, which are called forth by the disparaging nature of Dr. Urquhart's remarks in a communication in your last issue. I believe it will be admitted first of all by Dr. Urquhart himself that I have claims to be heard.

I believe Dr. Urquhart to be in the wrong in the views he holds of the working of the system of female nursing, yet I do not hope to convince him of his errors. In a matter of this kind, where lifelong habits and prejudices, and even amour 